Complutense Journal of English Studies

ISSN: 2386-3935

\title{
The Heavens and Hells of Scottish Literature: An Interview with Alasdair Gray ${ }^{1}$
}

\author{
Paula Argüeso San Martín²
}

Since the interwar period, discussions on Scottish literature have recurrently touched upon the causeeffect relationship between Scotland's political dependence on Britain and a state of cultural and artistic incompleteness. One of the most outstanding proponents of this crippling linkage between political and literary identity was Edwin Muir, who, in the influential Scott and Scotland (1936), pessimistically diagnosed a "predicament" or crisis for the Scottish writer, who lacked "a singular, autonomous" language (Bell, 2004, 8). For certain members of the Scottish Literary Renaissance-clearly Muir himself, but also others like Lewis Grassic Gibbon and Hugh MacDiarmid (Bryce-Wunder, 2014, 89-90)_, the artistic limitations of Scottishness were most severe in industrialised urban centres, which lacked the "purity" of rural areas, untarnished by the malevolent forces of modernisation. As James Robertson puts it: "Scottish literature has had an uneasy relationship with both the concept and the reality of the city" (2011). The model of the creatively stifling Scottish urban space proposed by various interwar authors permeated the work of Scottish urban writers, who often stagnated in cliched and sentimentalised portrayals of brutal city life, represented by genres like the urban kailyard or the gang novel (Burgess, 1998, 69). Against these limitations, Alasdair Gray offered a combination of tribute and innovation, which simultaneously located fiction in the suffocating and grim imagery of the Scottish urban tradition, while envisioning fluid, heterogenous and rich portrayals of what Glasgow and Scottish cities could imaginatively become.

Gray's first novel, Lanark (1981), is a two-part narrative that blends social realism —in Books I and II-with fantastic dystopia - in Books III and IV. Its protagonist, artist-in-the-making Duncan Thaw-whose alter ego in the fantastic sections is called Lanark - argues in Book II, that "[i]maginatively, Glasgow exists as a musichall and a few bad novels" (1981, 243). Such perspective reflects the traditional theme on the impossibility of writing a Glasgow novel, represented by works like Archie Hind's The Dear Green Place (1966). Yet, the epic dimensions of Gray's novel show his attempt to remedy this representational scarcity. Glasgow's lifeless and bleak tenements are, in Gray, the site of supernatural phenomena: a mouth swallows Lanark on top of the Necropolis, a tunnel is built under the basement of the Glasgow Art School in "The Cause of Some Recent Changes" (1983b, 11-16), and a dead woman's body is surgically brought back to life in the Victorian Glasgow pastiche of Poor Things (1992). Not only was Gray exceptionally original in his thematic choices, the manifold and changing urban scenarios he explored were technically conveyed as nudging the boundaries of canonical narrative structure and toying with polyphony - in the Ministry of Voices section of 1982, Janine - , fragmentation - Lanark starts with Book III, flouting chronological arrangement—, visual addenda and typography_-varied fonts and sizes as well as illustrations are integrated into the text of Poor Things — and also intertextuality. Moreover, encouraged by his inclusive and critical worldview, Gray revealed the absolutes of History, Truth, Time, Space and Authority_political and narratorial— to be subjective fictions which could be contested by other voices and other versions.

In "The State of Scotland - A Predicament for the Scottish Writer?" (1983a), a special issue of the journal Chapman devoted to the discussion of Muir's predicament one year after the reprinting of the first edition of Scott and Scotland, Gray examines the prevalence of this model and questions its contemporary validity. For Gray, Muir's understanding of Anglo-Scottish linguistic hybridity following the Act of Union of 1707 as being an artistically disabling factor for the Scottish writer constitutes an "act of cowardice" (1983a, 35-6); an act of conformism towards a perceived inferiority which, however, appears completely oblivious of the healthy state of Scottish literature: "The fact that Scotland is governed from outside itself, governed against the advice of

\footnotetext{
This research was supported by the Spanish National R\&D Programme, project RTI2018-097186-B-I00 (Strangers and Cosmopolitans: Alternative Worlds in Contemporary Literatures), financed by MCIU/AEI/FEDER, EU, and by the R\&D Programme of the Principado de Asturias, through the Research Group Intersections (grant number GRUPIN IDI/2018/000167). 
three parliamentary commissions and against the wishes of most Scots who voted on the matter, cannot be used to explain our lack of talent because that lack is no longer evident" (1983a, 9).

Indeed, the unprecedented boost in Scottish literary production which began in the 1980s proved Gray right. Although subsequent Scottish urban writers did not exactly follow Gray's thematic and formal synthesis of realism and fantasy, his ambitious experimentation and that of his contemporaries, James Kelman, Liz Lochhead, Tom Leonard and Edwin Morgan, instilled in later writers the confidence to gradually distance their work from the narrow and static models of stark realism and helped open up a wider range of creative possibilities for those writing in and about the Scottish urban. In fact, Janice Galloway has stressed Gray's ability to make her "feel braver" $(1995,196)$ as a writer: "Alasdair Gray's was a voice that offered me something freeing. (...) it was a voice that took for granted it wasn't the only voice" $(1995,194)$. Gray's liberating influence can be traced in Galloway's typographical representation of female fragmented subjecthood, as well as in A.L. Kennedy's disorienting exploration of gender, history, time and space subjectivities; in Jackie Kay's diverse queer and ethnic stories; and in Suhayl Saadi's radical rendition of the heteroglossic identity of the Glasgow Pakistani Community. Other names like Irvine Welsh, Laura Hird, Agnes Owens, Leela Soma, Zoë Strachan, along with those of contemporary crime fiction authors Denise Mina, Ian Rankin and Louise Welsh, also inevitably come to mind when examining the reach of Gray's creative seed.

After his sad passing on 29 December 2019, the publication of this interview, one of the last he gave (15 February 2019) constitutes a celebration of Gray's life and work and a reminder of his pivotal role in awakening Scottish fiction from its paralysing and regressive self-obsession and into the varied and outwardlooking approaches which currently fill the pages of Scottish writers.

Paula Argüeso San Martín: How important is Glasgow in your fiction?

Alasdair Gray: Glasgow has provided me with a lot of material, of course; however, it's as unimportant to me as St. Petersburg was to Dostoyevsky. Some of my writing has been based on trying to construct a different world to the one I experience, and I think one of my best bits of story writing is "Five Letters from An Eastern Empire" (1983: 85-133), in which I was inventing a completely imaginary world, and greatly enjoyed doing so. Again, there's another example like that in my novel, which has done wonders but was mostly ignored by critics, A History Maker, which is, I suppose, a future science fiction novel. Again, I rather enjoyed inventing a society in this novel: a benign future society. One in which men fought war games for fun but women and children weren't necessarily involved.

PAS: Could we say then that in your fiction there is more attributed to imagining spaces than just a realistic approach to them? But, in your first novel Lanark there is a mixture of both realistic and imagined spaces, and in a way the imagined spaces are based on reality, on both Glasgow and Scotland.

AG: Oh, they are, yes. That's exactly the case. Of course, the imaginary, the exaggeration of Glasgow, the city of Unthank, was an exaggeration of various factors of Glasgow that I remember knowing very well. At the time, post-war Glasgow was a working industrial city; it was given to very thick fogs and a very soot-laden atmosphere, to the extent that it lay across the valley like a kind of lid very often, so that you could see, blurred in an overcast soot-laden sky, the hills to the North, the Cathkin Braes to the South, a glimpse of brighter weather... Glasgow was often covered in soot contamination, preventing light to go through this lid, so it was dark most of the time.

There are other scenes in my novels which are a supernatural exaggeration of my own personal experiences. For instance, Lanark and Rima's journey along the Intercalendrical Zone in Lanark's Book IV was based on an occasion on which, in the very early months of my first marriage, when my wife was pregnant, we hitchhiked down to London to visit a wedding reception of a friend there and we did it very incompetently. The experience of walking with my wife along a strip of motorway was terrible. Motorways were a new thing and we hadn't realised that we couldn't just thumb lifts from lorries on motorways. We were walking along the motorway very late at night and very early in the morning, being unable to leave the motorway or to get any vehicle to pick us up. It was in part an exaggeration of that particular phase of my marriage that the crossing of the Intercalendrical Zone was based upon.

However, just like there are fictional spaces based on reality in my novels, I am also indebted to the supernatural and the exotic. I find I have been deeply influenced by these, both in my novels and paintings, especially the notion of heavens and hells as represented by Hieronymus Bosch and Brueghel. I was interested in the epic scale of Bosch's and Brueghel's works, as well as in some details of their paintings. In Bosch's vision of the Garden of Eden, the most sinister Garden of Eden when you look into it, you got God introducing Eve to Adam, but you also got a cat with a mouse in its mouth and creatures crawling out of horns, threeheaded birds and all kinds of mutations. In Brueghel's vision of The Fall of Rebel Angels you see the sky and the rebel angels turning into monsters as they fall, but in Bosch's version the rebel angels turn into a hoard of infectious insects. Here you have God constructing a Heaven in order to incubate these diseases to infect the Earth! Well, he's responsible for everything, what can you expect? 
In literature, I think of the notion of hells and heavens when classifying Kafka's novels. The Trial is rather like his hell; The Castle is a bit like his purgatory; and Amerika is even a bit like his heaven, ending with this vision of America being the home of this golden nature circus which can employ everybody! I remember, it must have been, I think, 1951. There was a great exhibition in Glasgow's art galleries and museums of Edvard Munch, and I was fourteen or fifteen at the time, and I was vastly impressed with his greatest paintings. I remember feeling: this is showing kinds of heavens and kinds of hells! Artistically, there has been no fight in me between what you might call the realistic and the fantastic.

PAS: Politics seem to be inescapable in your fiction from Lanark's Books III and IV to Jock McLeish's "POLITICS WILL NOT LEAVE ME ALONE" in 1982, Janine (1984: 231-2). Do you agree with the political role that has been attributed to Lanark by many critics as a novel which initiated a political awakening leading towards the second Devolution Referendum of 1997 ?

AG: When I was younger, in the 1950s and in the 1960s, the idea of Scotland becoming independent of England as a separate part of Britain entertained me. I found it an entertaining idea, not at all convincing, not at all necessary. When Harold Wilson's government was elected, and the Welfare State was expanded, it never occurred to us all that what the Welfare State had achieved for Britain was going to be undone by Margaret Thatcher. The worst undoing was, of course, the abolishing of the student grants. In the 1980s the student grants were replaced by debt. Most people from a working-class background, including myself, Jim Kelman and most Scottish writers at that time, got their university or art school educations as a result of these grants, and the thing is that, when Thatcher changed the grants, they became debt, so only those whose parents were pretty rich could ensure that they didn't leave their university education and so forth with a heavy burden of debt. This, of course, made me a hell of a lot more radical. Once people became afraid of losing their jobs, they stuck their necks out and criticised the authority... very clever. Myself, Jim Kelman and others were horrified and that's why I started thinking Scotland, independent, might become much more Labour, much more truly socialist. It might start recovering some of the socialist advantages that the British Tory government has abolished. Well, that hasn't happened as the Scottish government is imitating the English Tory government as much as it can. It's employing more and more English people in positions of responsibility, as the Head of the Constabulary. The Scottish legal system used to be separate from the English, while now they are practically identical. Anyway, as I say, Scotland as a separate government, I looked forward to it taking an independent line from Westminster and it hasn't, it hasn't at all. So, I am thoroughly disappointed in that. But my book was never planned as a prophetic vision.

PAS: To continue with Scotland and politics, in Poor Things there is a portrait of the main character, Bella Baxter, depicted as a symbolic personification of Scotland, Bella Caledonia. This use of the woman-as-nation trope suggests she could indeed be interpreted as an embodiment of the Scottish nation. In a specific section of the novel, Bella Baxter calls herself a "woman of the world" celebrating the growth of knowledge and awareness that travelling provides $(1992: 47,142)$. Should the Scottish independent nation-state you call for in your political essays be internationalist, open to diversity and willing to engage in a cosmopolitan vision of the world?

AG: Of course! I see it as a step in the right direction. Very big nations become very big bullies, therefore I would support the European Union. You've got so many European thinkers, Kurt Vonnegut and others, declaring that the USA is no longer their homeland in its present condition, and Fukuyama, the Harvard professor who at one point assumed that History was coming to an end. He theorised that as Communist states are becoming capitalist, there would be no reason for wars. And I'm thinking, yes, I hope that all big empires break up into independent states because a socialist co-operative democracy is more possible in small countries. Sorry, that's all PON-TI-FI-CA-TING.

However, as regards the current state of the world, I am more concerned with events related to our own survival as human beings. A professor of 'something or other' in the United States was interviewed by a team of multimillionaires, oligarchs and heads of global trust funds to advise them on what to do after what they called THE EVENT, which from their point of view was a total collapse of civilisation that is bound to happen pretty soon: climate change. He discovered that to them the problem was not how to prevent it happening. Their only problem was they will require a strong body of security guards to protect them from those who were not sharing their bunker facilities and how could they ensure that they could keep the security guards safe, unlike the overwhelming mass of the world population who were going to be dying off. I found it a very depressing notion, because it looks as if climate change is becoming dangerous. Then I remembered that in the late 1950s we had rather a similar situation. The world governments were telling people in Britain and other countries as well not to worry about nuclear warfare, because a number of air-raid precautions were going to make the population survive it. They were saying to build these huge underground bunkers for themselves and Switzerland was the only country that was building huge underground bunkers for its entire population. Anyway, about twenty years later or twenty years ago or both, they realised there was no point in constructing underground bunkers because if there was a nuclear war it would create such widespread damage that people 
couldn't live in underground bunkers forever, they would have to come up, and they would come up to a poisoned world. Therefore, you found that leaders of world governments were accepting what leaders of the Campaign for Nuclear Disarmament had been saying twenty years earlier, people like Bertrand Russell and others: you must agree not to have this kind of warfare.

It occurs to me that something like that might eventually trickle through to the rulers of our global economy, but in fact they can't ensure their own survival as a separate unit, separate from the rest of humanity. I hope that they realise that the best chance of their own survival is to do the best they can to help us all. Anyway, that is my main hope.

PAS: Your male characters are quite isolated and solipsistic individuals and some of them are tortured by madness. Do these qualities - isolation, solipsism, madness - lie within the characters themselves? Or is it a result of how they process the bleak post-industrial environment surrounding them?

AG: I don't know. I suppose what I think is my best novel, 1982, Janine, is in many ways my favourite book because the central character is a more ordinary kind of Scottish professional bloke and an electrician who installs security systems. I present him as a kind of working-class Tory and a very miserably isolated sod who has not been decent to the first woman in his life, and has a rather unhappy relationship with his legal wife, who separates from him. His life really has been a matter of masturbatory fantasies in the main. Ever since he failed to be decent to the first two women in his life, he entertains himself through fantasies. Eventually, he comes to realise that the imaginary woman he keeps dominating, and bullying and torturing, Janine, is really his own soul! But what's actually wrong with his life is simply that he is a tool of other men and he is employed to install security systems, a job he can do, a purely technical job, but one that doesn't satisfy him emotionally or imaginatively. Therefore, he realises that in order for him to change his life, to change his soul, to change his mind, which is what is necessary, he must first of all give up his job and start living differently in every way possible. Anyway, I was quite pleased, because there's an English novelist, Jonathan Coe, who liked my work and he told me that when reading 1982, Janine he thought it first to be propaganda for the Conservative Party. He didn't realise until the very end that it was going in the opposite direction. Anyone who wants to write a socialist novel and does it by building a good character who is completely socialist would be utterly unconvincing!

One of the things that James Joyce said in The Portrait of the Artist as a Young Man was that only true beauty and art doesn't move (people), only improper art moves, and that is pornography and propaganda, and this I agree with thoroughly. 1982, Janine is full of pornography and also propaganda which pretends to be propaganda for the Conservative Party, but at the very end it turns out not to be.

PAS: And there's this type of character, like Jock McLeish in 1982, Janine, a really isolated working-class man who struggles at engaging in meaningful relationships. This type of character can also be seen in James Kelman's fiction. Could you elaborate on your relationship to James Kelman and in which respects your artistic and political visions are similar to or different from each other?

AG: Jim and I share most of the same opinions about politics and art. My favourite book of his is The Busconductor Hines, because there he does present a central character, the bus conductor, who is also presented as a very decent family man who loves his wife and cares for his son. We showed each other our work as we were writing it, we first met at a writer's group led by friend Philip Hobsbaum, and I read a chapter of my novel Lanark and he read one or two of his short stories, and I thought them tremendously good. The chapters I read were from the crossing of the Intercalendrical Zone in Lanark, and Jim didn't like it very much at all. From his point of view, it was completely surrealistic and unrelated to real life.

PAS: Thank you very much for this conversation. I have received some unexpected and deeply interesting answers.

AG: I'm glad. My pleasure.

After leaving Alasdair Gray's home I decided to stay in Glasgow's West End and see some of the works he had painted on the walls of neighbouring buildings. The sight of the Hillhead Subway mural in which Gray maps out his own vision of the Hillhead area and the University, combining detailed illustration of the buildings and streets with an exotic classification of the myriad creatures who roam them, intensifies what is still a lingering thought after my conversation with him: that imagination and reality intersect in a mutually inclusive way, as two necessary realms of the same world.

\section{References}

Bell, Eleanor (2004). Questioning Scotland. Literature, Nationalism, Postmodernism. Hampshire and New York: Palgrave MacMillan. 
Burgess, Moira (1998). Imagine a City. Glasgow in Fiction. Glasgow: Argyll Publishing.

Bryce-Wunder, Sylvia (2014). Glasgow, Anti-Urbanism, and Scottish Literary Renaissance. European Journal of English Studies 18: 86-98.

Galloway, Janice (1995). Different Oracles: Me and Alasdair Gray. Review of Contemporary Fiction 15: $193-196$.

Gray, Alasdair (1981). Lanark. A Life in Four Books. Edinburgh: Canongate.

Gray, Alasdair (1983a). A Modest Proposal for By-Passing a Predicament. Chapman 35-6: 7-9.

Gray. Alasdair (1983b). Unlikely Stories, Mostly. Edinburgh: Canongate.

Gray, Alasdair (1984). 1982, Janine. Edinburgh: Canongate.

Gray, Alasdair (1992). Poor Things. London: Bloomsbury.

Hind, Archie (1966). The Dear Green Place. London: New Authors Ltd.

Robertson, James (2011). The City in Scottish Literature. Unpublished talk given on 9 February 2011 at Edinburgh Napier University. 